\title{
POLITICAL ATTITUDES AND ALLEGIANCES IN THE TOTOK BUSINESS COMMUNITY, 1950-1954
}

\author{
Twang Peck-yang
}

\section{Introduction}

Referring to politics in the totok Chinese community ${ }^{1}$ in Indonesia in the 1950s, Professor Skinner has stated:

During the decade from 1948 to 1958 , the struggle between Communist and Kuomintang partisans permeated all levels of Totok society, and in consequence foreign Chinese in Indonesia are highly politicized. There is evidence to suggest that by 1957 a neutral or moderate position was fast becoming untenable. ${ }^{2}$

Such a statement is typical of the way Western scholars have tended to depict the political struggle within the totok community at this time as primarily between "Communist" and "Kuomintang" partisans. This article is designed to show that rather than being dominated by the ideological struggle between Taiwan and the mainland, during the early 1950s the behavior of the totok Chinese business class in particular was primarily determined by their insecure domestic position as a pariah-entrepreneurial group in a potentially hostile, even dangerous environment .

Physically different from the Indonesian majority, occupying an important and visible economic position, and long regarded with considerable suspicion, the Chinese community of Indonesia, both totok and peranakan must have viewed the coming of Indonesian independence from the Dutch with anxiety. The fears of the overseas Chinese with regard to their future within Indonesia were complicated by the fact that at almost the same time as The Netherlands transferred sovereignty over the archipelago to the Republican government of Indonesia, the Chinese Communist Party completed its rise to power in China.

1. The distinction between the totok and peranakan communities in Indonesia has recently been described as follows: "Since about the beginning of this century, it has been possible to distinguish two groups of Chinese in Indonesia, on the one hand the totoks (literally, 'of pure blood') being those who had recently immigrated, spoke Chinese and were culturally oriented towards China, and on the other the much older peranakan communities being characterised by the use of the vernacular language for everyday purposes and by a distinctive set of cultural traits which were neither wholly Chinese nor wholly Indonesian." J. A. C. Mackie and Charles A. Coppel, "A Preliminary Survey," in The Chinese in Indonesia, Five Essays, ed. J. A. C. Mackie (Melbourne: Nelson, 1976), p. 5.

2. See G. William Skinner, "The Chinese Minority," in Indonesia, ed. Ruth T. McVey (New Haven: HRAF, 1963), pp. 115-16. An earlier survey of totok politics by the same author can be found in his Report on the Chinese in Southeast Asia, Southeast Asia Program Data Paper (Ithaca: Cornell University, 1951), pp. 63-73. 
The period of totok politics under review, then, took place at a time when substantial changes were occurring in Indonesia's domestic and international situation which profoundly affected the position of the Chinese in Indonesia. In 1950, the Hatta government granted recognition to the Chinese People's Republic (CPR). Shortly before, by the agreements reached between the Dutch and the Indonesians at the Round Table Conference in The Hague, Indonesian local-born Chinese were given a period of two years to opt either to remain as Indonesian citizens or reject that status. This faced a Chinese with the following choices: to become an Indonesian citizen; to become a citizen of the CPR; or to be stateless; for with the Hatta government's recognition of the new government in Peking as the legitimate government of China, only citizens of the CPR, not those of the Republic of China (RC) on Taiwan, would be considered "legal Chinese citizens" in Indonesia. For a business group the disadvantages of being stateless were high, and such considerations as the need for protection, to conduct trade outside the country, and to have a passport to carry out business trips abroad would make it likely that many of them would incline towards opting for Chinese citizenship.

\section{Economic Position and Political Orientation}

In discussing the political orientation of totok businessmen, it is essential first to consider what kinds of totok Chinese are covered by the term "businessmen," and how significant was the proportion of such businessmen in the total totok population in Indonesia. Totok Chinese society in Indonesia was largely formed during the last decades of the nineteenth century and the first decades of the twentieth. By the mid-1950s, the total population of Indonesian Chinese numbered about 2.2 million, ${ }^{3}$ of which perhaps 1.4 million were totok. ${ }^{4}$

There was no statistical survey of the proportion of totok Chinese involved in business during the period under review. But we may draw inferences from the rather careful 1930 census, which included a general survey of the occupational structure of the total Chinese community (both peranakan and totok). This portion of the census indicated that the major occupation of the Chinese was commerce, which accounted for over a third (36.6 percent) of working Chinese. About a fifth were engaged in industry, mainly as small craftsmen. The remaining working Chinese were engaged in garden agriculture, or coolie labor on plantations and in mines. ${ }^{5}$ There is little doubt that between 1930 and 1950 the economic status of

3. See Skinner, "Chinese Minority," p. 100.

4. The percentage of totok Chinese is calculated by projection from the census of 1930. After the 1930s mass immigration from China was officially prohibited. See Leo Suryadinata, "Indigenous Indonesians, The Chinese Minority and China: A Study of Perception and Politics" (Ph.D. dissertation, The American University, Washington, D.C., 1975), pp. 119-20.

5. The above information is cited from J. S. Furnivall, Netherlands India: $A$ Study of Plural Economy (Cambridge: Cambridge University Press, 1939), p. 412. According to the same census, more than half of the Chinese in Java were involved in trade, while Chinese outside Java were more likely to be peasants, farmers, plantation workers, or fishermen. But it should be noted that a trader might be anything from a peddler to a magnate and the number of the former was very much greater than the latter. Chinese involved in industry included unskilled laborers and skilled artisans, as well as factory owners. Mackie and Coppel, "A Preliminary Survey," pp. 7-8. For a more thorough treatment of the Chinese economic role during the colonial period, see W. J. Cator, The Economic Position of the Chinese in the Netherlands Indies (Chicago: University of Chicago Press, 1936). 
many Chinese improved. In the early '50s, a considerable proportion of the Chinese, mainly those living in Java, were retail traders and rural middlemen who purchased smallholders' agricultural commodities throughout Indonesia. They may be considered as petty capitalists. In addition, there were a certain number of Chinese capitalists who played an important part in wholesale trade, such as import-export, industry, finance, and transport services, although their economic power was not yet comparable to that of the still dominant Western entrepreneurs in Indonesia. ${ }^{6}$

However, as our concern is with totok Chinese rather than Indonesia's Chinese community as a whole, the economic position of many totok in the early 1950s has to be distinguished from that of the peranakan Chinese. The overwhelming majority of the totok Chinese who migrated to the Indies at the turn of the century began work as laborers, but within about half a century a number of them had improved their economic position considerably. In the business field, many left their peranakan counterparts far behind. This is evident from the totok businessmen's activity in the siang-hui, or business associations. Before 1910, in certain business associations, although "the new migrants [totok] had not yet risen to owning and managing their own business, they had become the more active members of the associations." 7 In other siang-hui, such as the Siang-hui Batavia, as early as the close of the first decade, totok members apparently outnumbered peranakan. ${ }^{8}$ These were indeed signposts pointing to the fact that certain totok businessmen at this stage were beginning to make their way in the field of business and to outstrip their peranakan counterparts. The shift of economic power from peranakan to totok businessmen continued during the next twenty years, until, by the mid-1930s, the widening gap between the two groups had become obvious. In 1934, the great majority of the participants in the founding meeting of the Siang-hui Federation were totok businessmen and the language used in the meeting was Chinese instead of Indonesian. Even peranakan newspapers commented that "the peranakan Chinese were left behind by their totok counterparts in commercial activities." 9 After the Second World War, many more peranakan fell to the rank of laborer or turned to other professions, and the business vacuum was partly filled by totok businessmen. 10

In the early '50s, "business" was the most frequently listed occupation of totok Chinese, especially in the urban areas of Java. ${ }^{11}$ In Jakarta, it was men-

6. For Chinese economic roles in commerce and industry, see Ralph Anspach, "Indonesia," in Underdevelopment and Economic Nationalism in Southeast Asia, ed. F. H. Golay, R. Anspach, M. R. Pfanner, and E. B. Ayal (Ithaca: Cornell University Press, 1969), particularly pp. 114-16, 182-84; see also J. A. C. Mackie, "The Indonesian Economy, 1950-1963," in The Economy of Indonesia, Selected Readings, ed. Bruce Glassburner (Ithaca: Cornell University Press, 1971), pp. 30, 44-45, 64-68.

7. Lea E. Williams, Overseas Chinese Nationalism: The Genesis of the Pan-Chinese Movement in Indonesia, 1900-1916 (Glencoe, Ill.: Free Press, 1960), p. 102.

8. Suryadinata, "Peranakan Chinese Politics," pp. 11-12.

9. Ibid., p. 99.

10. Li Ch'uan-shou, "Yin-tu-ni-hsi-ya hua-ch'iao chiao-yu shi" [The History of Chinese Education in Indonesia], Nan-yang Hsüeh-pao, 15, 2 (1959), p. 19.

11. See, for example, Chiao Ying, "I-tien i-chien ho hsi-wang" [Some Opinions and Hopes], Sheng Huo Pao (Jakarta), 1951 New Year Special Number. See also Wu Shih-huang, Yeh-ch'eng ta-kuan [A Description of Jakarta] (Jakarta: n.p., 
tioned that "generally these businessmen are either erh-p'an-shang (middlemen) or san-pan-shang (warung [small shop] owners)."12 The dominant role played by warung owners in Jakarta is indicated by the size of the Warung Association, which had more than 3,000 members. This organization came to be one of the most politically influential among all pro-KMT totok organizations. ${ }^{13}$ There were also other, still smaller businesses run by Chinese, for example the "stall businesses," which appeared in great numbers after the end of the war. ${ }^{14}$ By the term "businessman," then, I am referring primarily to entrepreneurs down to the level of petty capitalists.

(This focus on the Chinese businessmen in Indonesia, however, does not imply that there were no totok Chinese workers and peasants, particularly in the outer islands. During the early 1950 s various lower-class Chinese occupational organizations, for example the Federation of the Peasantry (Nung-min Lien-hohui), the General Federation of Workers (Chih-kung Chung-hui), and the Agricultural and Mechanic Association (Yen-i-chi-ch'i Kung-hui), were operating in different parts of the archipelago. ${ }^{15}$ )

After Indonesia recognized China in April 1950, totok businessmen were less active in expressing their political attitudes than, for example, the Chinese students. ${ }^{16}$ Views in the business community varied, not only by dialect group, 17

1951), p. 2; and Chen Chih-fei, "I-nien lai pa-tung hua-ch'iao k'ai-k'uan" [An Outline of the Padang Chinese in the Past Year], T'ien Sheng Jih Pao (Jakarta), January 1, 1952 .

12. Wu Shih-huang, Yeh-ch'eng ta-kuan.

13. Chung-Hsing, Yeh-chia-ta hua shang ya-lung kung-hui hung-i-shun kunghui fan-kung t'ou cheng chi shih [The Anticommunist Records of the Jakarta Warung Bond and of the Hung-i-shun Association] (Jakarta: n.p., 1952), pt. 1, pp. 7-47.

14. The stall runners formed their own occupational organization. In 1953, more than 800 Chinese stall runners were registered as members of the Stall Runners' Association ( $T^{\prime}$ an-sang Kung-hui) in Jakarta. The majority of the stall runners were said to have been shop watchers and workers. For a brief history of the development of the stall business, see "Yeh-chia-ta t'an-sang kung-hui ch'ichou-nien chi-nien te $\mathrm{k}^{\prime} \mathrm{an}^{\prime \prime}$ [The Special Number of the Seventh Anniversary of the Jakarta Stall Runners' Association], Sheng Huo Pao, November 12, 1953; see also Hsin Pao, July 26, 1949.

15. For such organizations in Palembang, see Hsüen Chi, "Chü-kang te ai-kuo ch'iao-tuan" [Patriotic Organizations in Palembang], Sheng Huo Pao, $1953 \mathrm{New}$ Year Special Number; for Pontianak, see Feng, "I-nien lai te k'un-tien" [Pontianak in the Past Year], Sheng Huo Pao, $1953 \mathrm{New}$ Year Special Number; for Belitung, see Sheng Huo Pao, February 22, 1952. In Bagan Siapiapi, the overwhelming majority of about 30,000 Chinese resident there were fishermen: see "Yin-ni te chung-kuo shih-chên" [A Chinese Town in Indonesia: Bagan Siapiapi], Sheng Huo Pao, April 24, 1951.

16. On Chinese student activity, see Twang Peck-yang, "The Internal Dynamics of Totok Chinese Politics in Indonesia, 1950-1954" (M.A. thesis, Monash University, 1979), ch. 2 .

17. The totok community as a whole was divided into a number of dialect groups, each of which tended to coincide--though the coincidence was not exact--with a certain economic position and a certain political orientation. Skinner has stated: 
but also from place to place ${ }^{18}$ and from individual to individual, and the outwardly expressed political attitudes of businessmen often changed with the changes in the Indonesian political climate. ${ }^{19}$ But although during the years under review their political orientation fluctuated, it can be suggested with some confidence that totok businessmen as a whole appeared to be China-oriented.

Professor Skinner has attempted to seek the reasons for this political orientation in the earlier history of the merchants' relations with China and with Sun Yatsen's revolution:

. . the relatively wealthy and well-established Hokkiens eschewed [Sun Yat-sen's] revolution and were thereby diverted from commitment to the KMT. In consequence they found themselves more flexible in the postwar world, better able to make a realistic adjustment to political changes. Moreover, as the dominant overseas merchants among the Indonesian Chinese, Hokkiens were inclined to back the political force destined to control the mainland Chinese ports with which they customarily traded. 20

It is clear, however, that such an explanation takes into account only external factors and not the concrete situation of the totok Chinese in the context of Indonesian society.

It is certainly true that in the early 1950 s the sentiments of totok Chinese (including businessmen) were primarily oriented toward China, or, more accurately, toward their place of birth. ${ }^{21}$. Without disputing the strength of such sentiments, I would nevertheless argue that they are less important in understanding the totok businessman's attitudes than are his political and economic position within Indone-

"Speech-group membership is one of the most important correlates of political alignment among the Indonesian Chinese: Hakkas tend to be rightist, Cantonese intermediate, while Hokkiens are decidedly leftist." See Skinner, "Chinese Minority," p. 116. Other scholars share this view. See, for example, David Mozingo, Chinese Policy toward Indonesia, 1949-1967 (Ithaca: Cornell University Press, 1976), p. 96.

18. KMT and pro-KMT totoks in certain areas, such as Aceh, seem to have dominated the totok political scene throughout these years. It was claimed that in Aceh pro-China organizations were in no way able to compete with the pro-KMT "righteous" organizations. This was also the case in Jambi. Other pro-KMT sources also claimed that in places like Bangka, Medan, and Pontianak, pro-KMT totok organizations were powerful in early 1952. See Tai Ch'ang, "I-nien lai yin-huashê-hui tung-t'ai" [The Situation of the Indonesian Chinese Society in the Past Year], T'ien Sheng Jih Pao, January 1, 1952; see also Tso Chou, "Sŭn-shui inien lai te ch'iao k'uang" [The Situation of the Surabaya Chinese in the Past Year], T'ien Sheng Jih Pao, January 11, 1952.

19. For the way the Indonesian internal political situation affected the totok political conflict, see Twang, "Internal Dynamics," ch. 6.

20. Skinner, "Chinese Minority," p. 494 n. 35.

21. This phenomenon is not unique to the Chinese but is also common among migrants of other races, such as Europeans who migrated to other parts of the world. See T'ien Ju-k'ang, The Chinese of Sarawak: A Study of Social Structure, Monograph on Social Anthropology, No. 12 (London: London School of Economics and Political Science, 1953), ch. 10. For expressions of totok Chinese sentiments towards their birthplaces, see, for example, Hsin Pao, November 17, 1950. 
sia, the history of his relationship with Indonesian society, and his feelings of insecurity within it.

\section{History of Insecurity}

Until the early decades of this century, although a white-collar, noncapitalist middle class existed in Indonesian society, 22 there was no genuine Indonesian middle class in a commercial sense. If one were to distinguish any such class there, distinct from Western entrepreneurs, it would have been composed mainly of some members of one ethnic minority--the Chinese. The first cry of the organized Indonesian nationalist movement was directed against this group, in particular against Chinese batik and kretek entrepreneurs. The Surakarta Sarekat Dagang Islam (Islamic Trading Society), formed in 1911, was initially a commercial organization, but it soon shifted its orientation to politics in an attempt to stop Chinese businessmen from penetrating "the last preserve of the Javanese merchant and industrial class." ${ }^{23}$ This attempt by asli (indigenous) entrepreneurs met with little success, and $C$ hinese continued to dominate the batik and kretek fields. But the move did give notice that Chinese entrepreneurs would be likely in the future to face a continuing organized challenge from their asli counterparts, and indeed the Sarekat Dagang Islam was later transformed into the Sarekat Islam, one of the major Indonesian nationalist organizations.

Despite latent Indonesian resentment of the economic position occupied by the Chinese in Indies society, relations between the two communities only occasionally erupted into violence before the Second World War, as in the anti-Chinese riots of 1918 and 1931 in Kudus and Pekalongan. ${ }^{24}$ During the early months of the Japanese occupation, however, Indonesian antagonism against the local Chinese led to widespread acts of vandalism and violence, with the result that "Peranakans and totoks in Java soon felt that they had more to fear from the Indonesians than from the Japanese . . . [and so] many chose to cooperate with the occupying power and entrusted their security to Nippon." ${ }^{25}$ (Here it should be noted that the choice by Indonesian Chinese to cooperate with the Japanese at a time when China was still at war with Japan already undermines arguments by Western scholars that totok politics were primarily an extension of the politics of China.) Their most serious ordeal was during the Revolution, when Indonesian mobs and irregular forces frequently attacked Chinese and their property, particularly during the early months and in areas being evacuated by the Republic. ${ }^{26}$ Feeling that the Indonesian

22. W. F. Wertheim, Indonesian Society in Transition: A Study of Social Change, 2nd ed. rev. (The Hague: van Hoeve, 1959), pp. 94, 232; see also George Kahin, Nationalism and Revolution in Indonesia (Ithaca: Cornell University Press, 1952), p. 28.

23. Ibid.

24. Donald E. Willmott, The National Status of the Chinese in Indonesia 1900-1958, Modern Indonesia Project Monograph (Ithaca: Cornell University, 1961), p. 12.

25. Mary Somers Heidhues, "Peranakan Chinese Politics in Indonesia" (Ph.D. dissertation, Cornell University, 1965), pp. 111-12.

26. See ibid., pp. 112-19. See also Chung-hua Tsung-hui [Federation of Chinese Associations] (Jakarta), Memorandum Outlining Acts of Violence and Inhumanity Perpetrated by Indonesian Bands against Innocent Chinese before and after July $21 s t, 1947$ (Jakarta: n.p., 1947). Until the latter part of 1949, many Chinese had fled the cities. In July 1949, it was reported that 5,000 totok were missing in 
government was affording them insufficient protection against this violence, various Chinese communities established their own security force, the Pao An Tui (Peace Preservation Corps), a body which, though defensive in purpose, was viewed by Indonesians as hostile to the Republic, ${ }^{27}$ because it $w$ as given arms by the Dutch. Its formation, then, intensified Indonesian resentment against the Chinese supporting it.

The Japanese occupation had served to some extent to enhance the position of certain asli entrepreneurs vis-à-vis the Chinese business community. According to Sutter, a policy of limited Indonesianization of portions of the economy was publicly aired for the first time in $1944,{ }^{28}$ and by mid-1945, there were many signs of increased asli business activity. New business organizations such as the Susunan Ekonomi Bangsa Indonesia Islam (Islamic Indonesian Economic Organization), Gabungan Perusahaan Barang2 dari Karet (Association of Rubber Products Companies), and Gabungan Pertukangan Kulit dan Karet Bangsa Indonesia Cirebon (Association of Indonesian Hide and Rubber Merchants of Cirebon) were set up. In July 1945, a conference called Permusyawaratan Kaum Ekonomi Indonesia Seluruh Jawa (All Java Conference of Indonesian Businessmen) was held in Bandung and many distinguished guests attended, including Hatta and Sukarno. Not surprisingly, the first of the five resolutions passed in this conference was "that a Persatuan Tenaga Ekonomi Bangsa Indonesia (Union of Indonesian Businessmen) be established." 29

Of the three years following the Indonesian declaration of independence, however, only 1946 saw a relative increase in asli business activity. In 1947 and 1948 , as a result of the struggle against the Dutch, losses of territory and economic resources, and a tightening Dutch blockade, only a few new businesses were established. Perhaps in consequence asli businessmen began to receive more attention and assistance from the government, with the BRI (Bank Republik Indonesia), for example, deciding in late 1946 that it would give greater attention to asli businessmen. Meanwhile the term "middle class" seemed to appear more frequently in the Indonesian press, and a "middle class" bank (the reoriented BRI) was set up. Also, business conferences were held by organizations such as the Sarekat Dagang Islam Indonesia (Indonesian Islamic Trading Society)--an organization reminiscent of the one formed more than three decades earlier. In concluding his discussion of the four years of the development of indigenous Indonesian business, Sutter allowed that "it is a fact that most of the few old Indonesian companies did expand operations during this period, and a number of new ones did arise, many of which would prove to be viable." 30

However, it was not until the Round Table Conference of August 1949 that the Republican government formally declared that its economic policy was to favor the "economically weak groups." An important segment of the Republican delegation

East Java and an unknown number of the Chinese were held in different parts of Indonesia by the Indonesian military.

27. See Charles A. Coppel, "Patterns of Chinese Political Activity in Indonesia," in Chinese in Indonesia: Five Essays, p. 41.

28. John O. Sutter, Indonesianisasi: Politics in a Changing Economy, 1940-1955, 4 vols. , Southeast Asia Program Data Paper (Ithaca: Cornell University, 1959), 1 , p. 270 .

29. Ibid., p. 262.

30. Ibid., 2, p. 637 . 
to the conference was the Financial and Economic Affairs Committee, headed by then Minister of State Ir. Djuanda. The major task of his committee was to draft an agreement concerning the business privileges to be given to ethnic groups in Indonesia. Article 11 of the Financial and Economic Agreement, signed on November 2, 1949, stipulated that the Federal Republic of Indonesia (RIS) had the right to make "such regulations as are necessary for safeguarding national interests and protecting economically weak groups." ${ }^{31}$ Under the terms of this agreement Djuanda later proclaimed, among other things, that Indonesian importers would receive government protection so that they would be able to compete with foreign importers.

One of the crucial steps taken in favor of indigenous Indonesian importers was the adoption in April 1950 of the Benteng (fortress) system. ${ }^{32}$ This was specifically intended to favor the "national importers," who included merely the "bangsa Indonesia asli." Under the Benteng system, in a move against the Dutch as well as the Chinese wholesaler, easily salable consumer goods were reserved by decree for national importers, and various government-owned banks and credit agencies were established. The scheme, however, "was beset by troubles from the start and resulted in the creation of only a handful of Indonesian bona fide importers, " 33 and the Indonesian government finally dropped the word "asli" in 1953.

Although until 1955 the degree of emphasis on "national enterprise" fluctuated from government to government, general policy did not change. By August 1953, 40 percent of all imports were technically in the reserved sector, ${ }^{34}$ and, in August 1954 , the Minister of Economic Affairs announced that 85 percent of all import licenses would be allocated to national importers. ${ }^{35}$ In other fields, such as transport and manufacture, alien Chinese confronted similar restrictions. But perhaps most significant of all was the fact that by May 1954, it was already being rumored that alien Chinese would not be permitted to run warung and other small enterprises in Indonesia. Keng Po published an article on May 4, pointing out that both the Minister of Economic Affairs (Mr. Iskaq Tjokroadisurjo) and the Minister of Finance (Dr. Ong Eng Die) had said that, in order to transform the colonial economic structure into a national one, the government would have to revise the 1934 business decree. The article further stated that the new business decree would prohibit alien Chinese from being hawkers, warung owners, and small entrepreneurs. Reportedly, the decree had already been drafted, and was awaiting Cabinet approval. ${ }^{36}$ Although the Minister of Finance denied Keng Po's statement a week after it appeared, the Union of Indonesian Businessmen welcomed the rumored decree.

31. Ibid., 3, p. 1017.

32. For an account of the Benteng system, see A. M. de Neuman, "On the Promotion of Indigenous Indonesian Industries with Special Reference to Credit Facilities for Private Business and for Local Government Enterprises," Ekonomi dan Keuangan Indonesia, 9, 11 (November 1956), pp. 698-99. See also Anspach, "Indonesia," pp. 168-78, and Sutter, Indonesianisasi, 3, pp. 1017-29.

33. Mackie and Coppel, "Preliminary Survey," p. 13.

34. Anspach, "Indonesia," p. 172.

35. Ibid., p. 173 .

36. "Kuan-yü chin-chih wai-ch'iao ching-ying ya-lung ho hsiao-ch'i-yeh te chuanshuo" [The Rumor about Forbidding Alien Chinese Running Warung and Small Enterprises], Sheng Huo Pao, Editorial, May 18, 1954. 
Faced with the post-1950 government policy of "Indonesianization" of the new nation's economy, totok Chinese society was well aware of its altered situation. To politically conscious totoks sympathetic to Indonesian independence, the changes were natural enough. To them, it was the Chinese businessman's responsibility to adjust himself to his new environment. As early as $1949 \mathrm{Hsin}$ Pao had warned huakiao (totok) that "those who want to continue living on this piece of land should have a new determination and a new understanding of the situation, or it may not be easy for them to retain a foothold any longer ... tung-ch'iao [fellow countrymen] should make a radical change in their attitudes. Whatever business we run, besides gaining reasonable profits, we also seek to serve the public. In particular the selfish attitude of profiting oneself at the expense of others . . . should be eradicated." ${ }^{37}$ In 1950 , after the Indonesian government's policy of Indonesianization had been set in motion, Hsin Pao again commented:

The period of colonial domination of the economy is close to the end. The history of untold exploitation and squeeze has come to its last chapter. From now on, hua-kiao's economy must extricate itself from the position of being the tool of the overall colonial economy. . . .

Although the colonial economic power remains firmly rooted . . . the Indonesian national economy is growing day by day. Even though it is still in the burgeoning stage, it is subjected to various kinds of political privilege; in addition, the government does not deny its role in fostering the Indonesian national economy. From now on, all forms of Indonesian national business and industry may secure the government's protection . . . the development of the Indonesian national economy from its infant stage to maturity is merely a matter of time. ${ }^{38}$

One may then consider the period from the declaration of Indonesia's independence to the early 1950 s as a transitional period in terms of the changing position of the totok Chinese business class. Employment of the term "Chinese middle class" ${ }^{39}$ by the Indonesian nationalist press, and the appearance of the selflabeled indigenous "middle class" may not be without significance. It seemed impossible for the two "middle classes" to advance at the same time, and the "foreigners" had therefore to take second place. In the early '50s, when the Revolution was barely over, the government's economic policy did constitute a very real threat to the totok Chinese business class. In this situation, it was natural that many of its members should seek protection from China, in order to play safe and to avoid the feeling that they were helpless and abandoned.

\section{The Search for Protection}

After the transfer of sovereignty, the Chinese community, although still constituting a major part of the business class of Indonesia, faced major obstacles to developing either its position or its security. Even if it were able to remain important economically, there was no possible way for it to assume a major position in Indonesian politics, and, in turn, attempt to secure or consolidate its economic position politically. In other words, Chinese businessmen were without political power. So long as they were seen as a foreign minority, the Chinese in Indonesia

37. Hsin Pao, July 16, 1949.

38. Ibid., August 4, 1950.

39. See, for example, "The Chinese Middle Class," The Voice of Free Indonesia, November 2, 1946. 
could never repeat the experience of the middle class in Western Europe, which developed a basis of economic power from which it then proceeded to attain political power. Nor were the Indonesian Chinese able to follow the example of their counterparts in the Philippines, ${ }^{40}$ where the Chinese mestizos did succeed in merging with the indigenous elite to form an important portion of the middle class as well as of the ruling class. ${ }^{41}$ (In that case the contradiction in the position of the Chinese was resolved by their ceasing, in effect, to be Chinese.)

Because of the contradiction between their economic and political position, the Indonesian Chinese had to remain a politically dependent business class along two dimensions, internal and external. First, Chinese businessmen, or the "pariahentrepreneurs," were dependent on local "elite-operators" ${ }^{42}$--political power-holders who were ethnically not Chinese. Second, the Chinese and Chinese businessmen looked outside Indonesia, to their homeland, for political protection.

To the Chinese business class, the first of these dimensions must be seen as essentially one form of "protection." From the outset it is hard to imagine any modern business which does not involve interaction with the state bureaucracy. Businessmen need the help of bureaucrats to ensure that the smooth-running of their businesses not be jeopardized by red tape, or the withdrawal of licenses, credits, business access, and so on. Chinese businessmen were no exception to this rule. On the other hand, the elite-operators, well aware of the special vulnerability of the Chinese business class, tended to exploit the situation to their

40. For the process of Chinese assimilation in the Philippines, see E. Wickberg, The Chinese in Philippine Life, 1850-1898 (New Haven: Yale University Press, 1965), and his "The Chinese Mestizo in Philippine History," Journal of Southeast Asian History, 5 (March 1964), pp. 62-100. The Chinese in Thailand had a similar experience: see William Skinner, "Change and Persistence in Chinese Culture Overseas: A Comparison of Thailand and Java," Nan-yang Hsüeh-pao, 16 (1960); see also The Siauw Giap, "Religion and Overseas Chinese Assimilation in Southeast Asian Countries," Revue du Sudest Asiatique (1965), pp. 67-83.

41. See Wickberg, Chinese in Philippine Life, and R. Constantino, Dissent and Counter-consciousness (Quezon City: Malaya Books, 1970), ch. 8.

42. Both the terms "elite-operator" and "pariah-entrepreneur" are used by Fred W. Riggs in his Administration in Developing Countries: The Theory of Prismatic Society (Boston: Houghton Mifflin, 1964). See, for example, pp. 116, 188-93. Joseph Jiang P.L. applied the model to the experience of several Southeast Asian countries during the colonial period and shortly after independence. See his "Political Change and Pariah Entrepreneurship" (Ph.D. dissertation, Indiana University, 1962). During the later part of the 1950s, Professor Wertheim used the term "pariah group" to describe the Indonesian Chinese business class; see Wertheim, Indonesian Society in Transition, p. 163.

"A pariah entrepreneur is a business undertaker (Verleger) belonging to a deviant community, more or less identifiable by ethnic origin, religious practices or other cultural symbols, and treated with suspicion and low esteen by the dominant community. He is given access to wealth and economic welfare through his business enterprise, but lacks legal, political and social power to protect himself and his wealth. Hence he can only survive by buying protection from the political elite. His social role and function are best illustrated by a sort of symbiosis in which he lives precariously with the elite." See Jiang, "Political Change," pp. 11-12. An "elite-operator may be an official or politician in government, or an influential person outside the government, closely linked with the elite." Riggs, Administration in Developing Countries, p. 190. 
own benefit, both in the colonial period (when the power-holders were mostly Dutch officials), ${ }^{43}$ and after independence.

Internal "protection" mainly involved the security and smoothness of day-today business operations, and it was usually a matter for individuals to arrange in relation to particular officials or official cliques. This form of protection, however, could not guarantee that, in times of serious social turbulence, the property and lives of members of the Chinese business class in general would be safe. The power of individual "elite-operators" was limited, and they were in no position to provide physical protection to their Chinese business clients in critical times. In such conditions, entrepreneurs hoped to secure some degree of "protection" from their homeland.

It is important to remember that the totok businessmen were a small, economically better-off, ethnic minority living amid a poverty-stricken majority of another race; their role as traders in an underdeveloped society was generally seen as exploitative; and agitation by leaders of groups within the indigenous society could easily arouse strong feelings against them. Their political milieu, then, tended to be precarious, and under certain circumstances, such as the chaotic period of nationalist struggle or later periods of xenophobia, their security was under direct threat. In such times of extreme difficulty, the last possible resort available to them was diplomatic pressure brought to bear from China.

The Indonesian Chinese nationalist and patriotic movement launched during the early decades of this century was not fully unconditional: many totok Chinese did expect something in return from China. Cheng Kung-po, the Minister of Industry of Nationalist China, after visiting the Nanyang including the Indies in 1934, pointed out that the patriotism of the overseas Chinese was sincere and vehement, but what they truly hoped for was the unity of China. But why the unity? One writer, after quoting Cheng, explained: "They [the hua-kiao] hope that China will unite, so that the government will be able to achieve the responsibility of protecting Ch'iao Pao [hua-kiao]; this is their greatest hope." From the early decades of this century the problem of protection of the hua-kiao was not an uncommon theme in the Indies Chinese political arena. In the 1930s, Ang Jan Goan, a staunch China-oriented peranakan leader, wrote: "The Chinese here often blame China for not being able to advance and protect the interests of her nationals, but why should we ask and blame China? Isn't it better to ask ourselves: what have we done, as nationals of China, for our nation and country?" 44 Such a statement reflected more than the nationalist belief of Ang Jan Goan; it also clearly illustrated the keen expectations of many Indies Chinese, especially totok Chinese.

When during the Revolution the Chinese community in Indonesia were in desperate need of protection, their efforts to secure external support were in vain. It was an historical coincidence that, immediately after they had experienced this period of insecurity and had come to realize the indispensability of protection from their homeland, China was at last "united." There seems little doubt that this coincidence had considerable consequences for the issue of their "political orientation."

After the transfer of sovereignty and the departure of the old colonial powerholders life within Indonesia certainly became more complicated for the Chinese

43. See Jiang, "Political Change," ch. 4 on "Pariah Entrepreneurs in Colonial Regimes" section B, "The Chinese in the Netherlands Indies," pp. 159-79.

44. Tan Hong Boen, Orang-Orang Tionghoa Jang Terkemoeka di Java (Solo: The Biographical Publishing Center, 1935), p. 189. 
businessmen. During the chaotic years of revolution, entrepreneur-elite relations --this time between Chinese businessmen and asli Indonesians--could not be solidly or widely established, and by the early 1950s, the Chinese business class felt threatened and insecure. ${ }^{45}$ "Many tung-ch'iao complained that it would be difficult to do business in the future, "46 and a gloomy atmosphere prevailed in Chinese business circles. In July 1949, one commentator said:

In recent years, the Hua [Chinese] businessmen's historical rights have been abolished; importation was restricted, entrepot goods subjected to circumscription . . . numbers of small stalls businesses suffered losses; life was getting harder; there was no room left for importers but taxes remained undiminished. If the Chinese businessmen were not vigilant against such crises, probably in the near future the so-called importers will decline from the position of erh-p'an-shang [middleman] to big warung runners, and small stalls will be on the brink of bankruptcy. ${ }^{47}$

In face of this pressure, and prompted by lingering nostalgia for his homeland, one writer remarked in 1952: "Over the last few years, as a consequence of the losses in business, a section of businessmen became politically conscious. They have only one hope: the motherland is becoming powerful. Wind up the business and return home. It is no longer easy to earn money here, and if the motherland is not powerful, it is useless to earn money." 48 Though it should not be accepted at face-value, such a statement does reflect to an important degree the disappointment of certain businessmen.

In October 1949 , at a time when the difficulties posed for the Indonesian Chinese by the Revolution had not yet ended, Communist China came into being, and half a year later, Sino-Indonesian diplomatic relations were established. It was at this juncture that the issue of political loyalty began to present itself directly to the overwhelming majority of the totok Chinese. The Nationalist government had by then withdrawn to Taiwan, but it continued its claim to be the legitimate government of China. To the many totok Chinese in Indonesia, including the businessmen, it appeared that if, after a few decades of rule in mainland China, the KMT should have proved unable even to maintain itself in power there, it could have no prospect, from Taiwan, of protecting the overseas Chinese. In addition, of course, the Taiwan regime was not recognized by the country in which the totok Chinese were residing. Mainly for these reasons, then, many totok businessmen, and, in fact, many other Chinese, tended to be China-oriented, or, as the pro-KMT press often put it, "pro-communist" or "leftist." Even pro-KMT writers helped to provide the explanation for businessmen tending to be China-oriented: "In our town, the majority of those who surrender to the communists are the Hokkiens. The bulk of them are fat-cats and magnates; this is because their initial motive is the preservation of their property." 49

45. The writer does not suggest that there was no "Ali-baba" business in practice at all during the early $50 \mathrm{~s}$. In fact this phenomenon was recognized by totok Chinese. See, for example, Fan I, "Lüeh-t'an yin-ni hua-ch'iao te chin-hsi" [A Brief Account of the Indonesian Chinese: Past and Present], Sheng Huo Pao, 1952 New Year Special Number.

46. Hsin Pao, July 16, 1949.

47. Ibid., July 26, 1949.

48. Fang Ts'un, "Hui-ku Solo i-nien" [Review of Solo in the Past Year], Sheng Huo Pao, 1952 New Year Special Number.

49. T'ien Sheng Jih Pao, January 1, 1952. 
In May 1950, the establishment of diplomatic relations between China and Indonesia was celebrated in Jakarta and other towns. According to a pro-KMT source, it was because at that time "the hua-kiao did not know the situation in China . . . that they felt that life and property needed protection" and they were thus "forced" and "pushed" to participate in the celebration. ${ }^{50}$ This statement was highly propagandist, but it did point to the crux of the matter.

There is little doubt that the pro-KMT faction was fully aware of the problem of protection for the totok Chinese. In October 1952, an Overseas Chinese Affairs Conference was held in Taipei, attended by 250 pro-KMT and KMT overseas Chinese from thirty different countries. A four-point proposal formulated by these delegates was prepared for submission to the Taiwan government. Not surprisingly, the first point proposed was: "To protect the interests of the Chinese abroad, especially those residing in the countries which have recognized the communist regime." 51

In addition to concern for their security and property, other factors also led totok businessmen to be China-oriented. In the period after the Second World War, a certain number of them still had their savings in China and, because of the precarious political position of the Chinese in Indonesia, they intended eventually to return to their country. But the "sweat and blood of half a lifetime melted into the air" following the withdrawal of the Nationalist government to Taiwan. ${ }^{52}$ Many of these totok businessmen, though they had lived in Indonesia for decades, still had kinsmen in their birthplaces, and some of them had property there too, in the form of land and houses. ${ }^{53}$ It would not have made sense if, after 1950 , they had espoused the cause of the KMT government.

\section{Nationality and Security}

The protection issue and the threat posed by the Indonesian government's internal economic policy also affected the political orientation of the local-born Chinese, as illustrated by the course and result of the issue of citizenship option. ${ }^{54}$

As mentioned earlier, during the Round Table Conference it was decided that Indonesian-born Chinese would be given two years--effective from the time the agreement was made until December 27, 1951--to decide their nationality. According to this agreement, local-born Chinese could reject Indonesian citizenship if they wished to become nationals of China. ${ }^{55}$

In making the decision to opt for one or other nationality, concern about their legal and economic position in Indonesia appears to have been more important to

50. Chung-Hsing, Yeh-chia-to hua shang, p. 8.

51. "Overseas Chinese Affairs Conference in Taiwan," Far Eastern Economic Review, January 1, 1953, p. 11 .

52. Hsin Pao, November 27, 1950.

53. There were Indonesian Chinese who were "absentee landlords" in their birthplaces. See Sheng Huo Pao, 1952 New Year Special Number.

54. For the Indonesian Chinese citizenship issue, see Willmott, National Status of the Chinese, chs. 3 and 8; see also Charles Coppel, "The National Status of the Chinese in Indonesia," Papers on Far Eastern History, 1 (March 1970).

55. The issue of nationality option was a complicated one, and in some cases it was even confusing; government officials made inconsistent statements concerning this issue. See Willmott, National Status of the Chinese, pp. 29-31. 
the Indonesian Chinese than any other consideration. As we have seen, the Round Table agreement on the nationality option was accompanied by a further agreement on "protecting the economically weak groups." This statement may have given rise to fears in the numerous community of local-born Chinese about their future economic treatment even were they to become Indonesian citizens. Events of the following years, such as introduction of the Benteng system outlined earlier, increasingly demonstrated that those who opted for Indonesian citizenship were, in fact, not granted the same privileges as were enjoyed by asli Indonesians.

Government policy evoked criticism from Indonesian citizens of Chinese descent. Siauw Giok Tjan, then a member of parliament, was most critical of the "indigenous policy." He suggested that racial discrimination was contrary to the national ideal of the Republic and argued that it prevented citizens of foreign descent from becoming genuine Indonesian patriots as stipulated in the Manifesto of November 1 , 1945. He argued that such discriminatory measures would lead to a system of "frontmen," 56 a system that was, in fact, beginning to develop between asli Indonesians and Chinese businessmen. Djuanda, as Minister of Prosperity, replied to these criticisms in July 1950:

The requirement that 70 per cent of the capital must be held by indigenous Indonesians is based on the Government's view that although it does not practice racial discrimination, it has the full right to make regulations to protect economically weak groups. . . . As is known, indigenous Indonesian nationals as a group are included amongst the economically weak. Of course, a few indigenous Indonesians are economically strong, but most of them are economically weak. Nationals in the country who are not indigenous Indonesians form the economically strong group. Of course, in that group, there are also economically weak persons, but these are only exceptions while most are in an economically strong position. By providing an opportunity for the capital of other than indigenous Indonesians to participate up to 30 per cent in Indonesian importing companies, the Government feels that sufficient opportunity has been given for healthy cooperation between citizens. 57

In August 1950, Siauw Giok Tjan in a parliamentary speech spoke of the "indigenous policy" in relation to the matter of the citizenship option:

According to international conventions of nationality, each nation has the right to formulate its own legislation on nationality and national status. As regards the problem of dual nationality, it could be resolved by arriving at an agreement with the country concerned. If the government intends to set the conditions by which one could become a citizen, a certain regulation may have to be implemented. But in no way could the problem be solved by forbidding Indonesian citizens to raise two national flags while at the same time implementing the "indigenous policy." 58

Here, Siauw strongly implied that the discriminatory economic policy was the reason for "Indonesian citizens" raising two national flags--that of the Republic of Indonesia and that of the People's Republic of China or, less likely, of the Repub-

56. Sutter, Indonesianisasi, 3, p. 1018.

57. Ibid.

58. Hsin Pao, August $14,1950$. 
lic of China. It is easy to believe that this domestic economic factor could well have affected the view of local-born Chinese about their future in the country, and consequently their political orientation.

Pro-KMT and KMT totoks were no less inclined to comment on the question of the national option by referring to the legal status that the local-born Chinese would enjoy if they were to become Indonesian citizens. This question became most pressing as the end of the period for the citizenship option approached. It was pointed out in December 1950 that many local-born Chinese "regret that so far the Indonesian government has not promulgated the nationality law. They are therefore unclear about whether or not they will be entitled to share the same legal protection and social welfare as the asli Indonesian." Thus, "with regard to the nationality option, they are in a state of serious hesitation." 59 On another occasion, a rally held in Jakarta by local-born Chinese was attended by Indonesian officials, who attempted to explain the rather confusing issue of the nationality option. A member of the rally complained to these officials that, according to the government regulation, local-born nationals were not to be discriminated against, but, in practice, this promise had not been kept. He further enquired whether the government had given serious attention to rectifying its discriminatory policy. Other local-born Chinese, such as the lawyer Tan Po Goan, raised the question of whether Chinese who became Indonesian citizens would be permitted to import benteng goods. The Indonesian officials avoided answering these questions. 60

It seems clear, therefore, that doubts about their basic nationality stat us if they became Indonesian citizens were important in leading many local-born Chinese to reject Indonesian citizenship. If such was the case for local-born Chinese, it was likely to be more so for China-born totok.

Indonesia's external economic relations with China may also have contributed to the pro-China leanings of businessmen. In December 1953, during the first Ali Sastroamidjojo government, Indonesia's first trade agreement with China was concluded. Although the total value of the trade provided for under this treaty was only $\$ 2$ million (for the year 1954), this was nevertheless a significant step which foreshadowed more sizeable future trade between the two countries. In August 1954 , the trade agreement was renewed for 1955, and the value of goods to be exchanged leaped to $\$ 16.8$ million. ${ }^{61}$ These improving economic relations accompanied the strengthening of diplomatic ties between Indonesia and China. To the totok businessmen, in terms of their business activity this was a desirable development. In this situation, Professor Skinner's explanation of the "leftist" leanings of wealthy merchants appears relevant. It is also worth noticing that, as Mozingo commented, Peking won a major victory in the early 1950 s when the Bank of China, the top Chinese financial institution in Indonesia, broke its ties with Taiwan and went over to the CPR. "This caused many wealthy and influential Chinese to follow suit." 62

\section{Legal Citizen or "Stateless" Chinese: A Choice}

Providing "protection" was one of the most attractive aspects of China's appeals to the overseas Chinese, and "protection" was a term very frequently empha-

59. Ch'êng Pao, December 3, 1951.

60. Ibid.

61. Herbert Feith, The Decline of Constitutional Democracy in Indonesia (Ithaca: Cornell University Press, 1963), p. 389.

62. Mozingo, Chinese Policy toward Indonesia, p. 96. 
sized in the pro-China totok press, particularly during the months following the establishment of Sino-Indonesian diplomatic relations. In the Common Program adopted in September 1949, China promised that "The Central Government of the People's Republic of China shall make every effort [chih li] to protect the proper rights and interests of Chinese residing abroad." 63 "This promise became the central theme of China-oriented newspapers, particularly after China's first ambassador, Wang Jen-shu, arrived in Indonesia in August 1950. On August 15, 141 China-oriented Chinese community organizations of Jakarta and 37 from the outer islands together held a large celebration to mark the arrival of the ambassador. ${ }^{64}$ In his speech on the occasion, Wang reaffirmed the promise to the totok Chinese and added that the new government would "protect the proper rights and interests of the hua-kiao seriously." 65 It is not necessary here to question whether Wang's statement was in a sense an attempt to qualify the original statement made in the Common Program. The term "protection" by itself was vague. To the Indonesian Chinese of Chinese nationality, such a general promise may have been more than satisfactory; but, on one occasion, Hsin Pao did mention the economic interests of the totok Chinese in the context of China's "protection." When the Indonesian government was still considering the question of setting up Chinese consulates in Indonesia, the pro-China totok press commented: "The purpose of setting up consulates is to foster commercial and industrial interests, and to protect the Chinese abroad." ${ }^{66}$ In any case, to totok businessmen in Indonesia and, more generally, to many of the Chinese community who had not opted for Indonesian citizenship and who had longed for decades for some protection from their homeland, the general promise was attractive enough.

China's policy toward the overseas Chinese did not, however, remain unchanged during the few years under review. In fact as early as mid-November 1950 there was an indication of a shift in attitude when the Chinese embassy made clear that for overseas Chinese to acquire Indonesian citizenship, they "would be required to obtain 'letters of explanation' from the Chinese government." 67 As

63. "Kung-t'ung kang-ling" [The Common Program], Article 58, Chung-hua jenmin kung-ho-kuo $k^{\prime} a i-k u o$ wen-hsien [Documents on the Founding of the People's Republic of China], cited in Stephen Fitzgerald, China and the Overseas Chinese: A Study of Peking's Changing Policy, 1949-1970 (Cambridge: Cambridge University Press, 1972), p. 81.

64. Hsin Pao, August 16, 1950. August 17 is the national day of the Republic of Indonesia. The reason why this particular day was chosen to celebrate Wang's arrival may be partly due to the fact that the Chinese embassy intended to emphasize the national friendship between China and Indonesia. On that day, Wang was mentioned in the pro-China press as a staunch supporter of the Indonesian Revolution. But there may have been one more reason that prompted the pro-China faction to choose that day to celebrate Wang's arrival. As many totok Chinese, whether Taiwan-oriented or China-oriented, celebrated the national day of Indonesia and raised the national flag of Indonesia, that of the CPR or RC was at the same time raised by the respective factions. The celebration on that day could serve as pressure on totok Chinese to show their loyalty to China. The situation was certainly unfavorable to Taiwan-oriented totoks.

65. Hsin Pao, August $16,1950$.

66. "O-kuo shê-ling wên-t'i" [The Problem of Setting up Chinese Consulates], ibid., Editorial, November 14, 1950.

67. Mozingo, Chinese Policy toward Indonesia, p. 93. 
Dr. Mozingo has pointed out, this implied that "Peking was prepared, in principle,
to renounce claims on some overseas Chinese. . ." 68 .

Significantly, almost at the same time as the Chinese embassy issued this declaration, an editorial of Hsin Pao, entitled "Which Way Would You Choose," seemed to echo the statement:

The period of dual nationality is over. This is the time for hua-kiao - . to make a choice of their nationality. Hua-kiao--especially those not locally born--have their next of kin, relatives and friends in the motherland; in particular they are consanguineous to the Chinese people [chung-hua min-tsu]. The magnificent landscape of the motherland, its culture and customs, all these remain in the mind and are unforgettable. But on the other hand, hua-kiao--especially those who are local-born--have been living in this country for generations . . . the fruits of their labor, the ground on which they earn their living are all located here. They would . . . find it hard to establish a foothold if they were to return to the motherland. ${ }^{69}$

This editorial had most likely received embassy approval before it was published. Its tone does not seem designed to encourage local-born Chinese to become Chinese citizens, but possibly reflects the Peking government's increasing awareness by late 1950 of its inability to provide actual "protection" for its overseas citizens, and the resulting necessity of adjusting China's policy towards them. These policy adjustments by the Chinese embassy in late 1950 should possibly be seen as a prelude to Peking's modified Overseas Chinese policy proclaimed later.

In January 1951, only fifteen months after China had promised to "make every effort" to protect the overseas Chinese, Ho Hsiang-ning, the Chairwoman of the Overseas Chinese Affairs Commission, announced that the situation of the overseas Chinese "is certain to become increasingly difficult," and that overseas Chinese should depend for their survival "on the strength of their own efforts." As Dr. Fitzgerald pointed out: "Although protection of Overseas Chinese was still proclaimed as a basic principle of Overseas Chinese policy . . . from the beginning of 1951 , self-reliance became the keynote of the policy for protection." 70 There was clear evidence that this policy of "self-reliance" was also applied to the Indonesian Chinese. After late 1950, the pro-China totok press began to play down the promise of "protection," replacing it by reference to the hua-kiao's "self-reliance." The decision of most, if not all, the local-born Chinese to opt for Chinese nationality, then, was not made at a time that Peking appeared most willing to "protect" them, but at a time that Peking's promise had receded into the background. In other words, it was largely during the months when Peking was urging the overseas Chinese to be self-reliant that most of the local-born Chinese made their decision to reject Indonesian citizenship.

By late 1951, which was close to the end of the two-year period of the citizenship option, the Indonesian Justice Department estimated that more than 390,000 Indonesian-born Chinese had rejected Indonesian nationality. ${ }^{71} \mathrm{By} 1953$, the number had increased to about 600-700,000. As Dr. Mozingo has put it: "Jakarta

68. Ibid., p. 94.

69. Hsin Pao, November 17, 1950.

70. Fitzgerald, China and the Overseas Chinese, pp. 81-82.

71. Skinner, "Chinese Minority," p. 111. 
greatly under-estimated the number of local-born Chinese who actually would go to the trouble to opt for Peking citizenship despite the fact that most Chinese had a petty-capitalist background and could have easily acquired Indonesian citizenship by simply remaining silent." 72

Although the overwhelming majority of the local-born Chinese opted for citizenship either of Indonesia or of the CPR, it should not be forgotten that the KMT faction was also involved in the issue. After the Nationalist government had retreated to Taiwan, the overseas Chinese were still regarded by that government as nationals of "China" (Republic of China). Indonesia recognized only the CPR and, in principle, if local-born Chinese were to reject Indonesian citizenship, and if they wanted to become "legal citizens" recognized by the Indonesian government, they had to opt for CPR nationality. In the face of this situation, the KMT totok Chinese faction could not remain silent. If it did, this would mean, in the eyes of all Chinese, including the pro-KMT Chinese in Indonesia, that it implicitly accepted the fact that there was one China--the People's Republic. This would further signify that the political leverage of the KMT faction would be seriously weakened in the eyes of all Indonesian Chinese. The most urgent task of that faction, then, was to try to prove to all the Chinese, and particularly to the local-born Chinese, that to be citizens of the Republic of China was not to be "stateless." The KMT faction did attempt this crucial task ${ }^{73}$--but was apparently unsuccessful in persuading local-born Chinese to become "citizens" of the Republic of China. Meanwhile, the pro-China totok did not lose the opportunity of emphasizing the differences between "stateless" Chinese and "Chinese citizens." It was often pointed out that only the "white Chinese," that is, Chinese with some Dutch blood, would want to be "stateless," and in Indonesia they would receive no diplomatic protection from the CPR. In addition, pro-KMT totoks would face other difficulties, such as obtaining a passport for overseas travel. ${ }^{74}$

It appears that, after Indonesia recognized China, a totok Chinese had no documentary proof that he was either a CPR national or was "stateless." This fact had consequences which seem to have been misinterpreted by some observers. In a situation where the identity of a totok Chinese could not be established, the most simple and common way for him to demonstrate his nationality was through the use of the national flag: totok Chinese who considered themselves nationals of China raised the "five-stars flag" at their homes during China's national day or on other occasions. ${ }^{75}$ Outwardly, this phenomenon could easily give the impression that these totoks were politically active, or ideologically pro-Peking, or even procommunist, and a seemingly logical inference was that totok society overall was highly political. In fact, this may not have been the case for the majority of the totok Chinese. Particularly among the totok business class, such considerations as the hope for protection, the need to have business deals with China and carry out business trips overseas, naturally led them to "opt" for China citizenship; and if they did so, they had to prove their identity by outward political symbols. Besides

72. Mozingo, Chinese Policy toward Indonesia, p. 97.

73. For a discussion of attempts by KMT forces in Taiwan and Indonesia to retain the allegiance of Indonesian Chinese, see Twang, "Internal Dynamics," $\mathrm{ch} .6$.

74. Ch'êng Pao, December 16, 1950; July 12, 1951.

75. Raising the five-stars flag was certainly a symbol showing oneself to be a citizen of China. The pro-China press encouraged the totok Chinese to "unite under the five-stars flag": see "T'uan-chieh tsai wu-hsing-ch'i-hsia" [Unite under the Five-stars Flag], ibid., Editorial, August 15, 1950. 
raising the "five-stars flag," if conditions allowed, such pro-China political gestures as verbal praise of the new China's development seemed to be required. This is certainly not to say that the political behavior of the totok Chinese businessmen was merely for effect; the genuine quality of their sentiment toward their homeland in the early ' $50 \mathrm{~s}$ is hard to deny.

In this article, I have attempted to explain the China orientation of the totok business class in Indonesia in the early 1950s. Attention has been drawn to a number of, mainly internal, political and economic issues which combined to account for their political behavior. There was a built-in contradiction in the position of the Chinese businessmen in Indonesia during the period under review: being an ethnic minority as well as a business class, they were necessarily politically dependent and were, therefore, compelled to seek both internal and external political protection in order to sustain their economic position in the Indonesian context. Internal political protection could only ensure the day-to-day operation of their business. External political protection became important in times of great social turbulence when not only the Chinese businessmen, but the ethnic Chinese as a whole, became the target of attack. This was most clearly evident during the years of revolution. When their basic survival was threatened, many Chinese were inclined to support whatever regime was willing to offer protection, as had been vividly demonstrated during the Japanese occupation. During the few years preceding the transfer of sovereignty, the vulnerability of the Indonesian Chinese even led them to beg protection from the collapsing Nationalist government.

The inability of the Nationalist government during the late 1940 s to provide any external protection for the Chinese in Indonesia was matched, after independence, by a dwindling of the internal economic protection they could expect from local patrons. This was a consequence of the Indonesian government's unfavorable domestic economic policy towards the Chinese in general, and particularly towards the totok business class, which they felt as a serious threat to their economic position. It $w$ as a historical coincidence that, immediately before 1950 , political events in both Indonesia and China caused a situation in which the Chinese business community lacked both internal and external protection, and this combined with their deteriorating economic condition to increase the attraction of Peking. In fact, had Peking not itself claimed to be the protector of the Chinese, many totok Chinese would probably have taken the initiative in demanding its protection or seeking protection elsewhere. It is ironic that, at just the time that many of them were opting for CPR citizenship, Peking itself realized its inability to provide protection and tried to encourage them to accept Indonesian citizenship.

The Hatta government's recognition of the People's Republic of China compelled almost all totok Chinese to take sides in the conflict between Taiwan and China, as from then on the only "legal Chinese citizens" in Indonesia were those owing allegience to Peking. After the disturbed years in Indonesia and with the rise of the new China, many totok Chinese, certainly including the businessmen, wished to end their bitter experience of being "overseas orphans." Basically, then, it was their concern for security that caused them to be China-oriented. 